\title{
THE RELEVANCE OF NUTRITIONAL STATUS AND HISTOPATHOLOGICAL FINDINGS ON THE INFECTIOUS PROCESS OF BALB/C MICE INOCULATED WITH Lacazia Ioboi
}

\author{
Adriana Sierra Assencio Almeida BARBOSA(1), Suzana Madeira DIÓRIO(2), Silvia Cristina Barboza PEDRINI(3), Adauto José Ferreira NUNES(4), \\ Andréa de Faria Fernandes BELONE(4), Sônia Maria Uso Ruiz SILVA(2), Beatriz Gomes Carreira SARTORI(1), Sueli Aparecida CALVI(5), \\ Fátima Regina VILANI-MORENO(1) \& Paulo Câmara Marques PEREIRA(5)
}

\begin{abstract}
SUMMARY
The aim of this study was to evaluate the effects of the protein-calorie malnutrition in BALB/c isogenic mice infected with Lacazia loboi, employing nutritional and histopathological parameters. Four groups were composed: G1: inoculated with restricted diet, G2: not inoculated with restricted diet, G3: inoculated with regular diet, G4: not inoculated with regular diet. Once malnutrition had been imposed, the animals were inoculated intradermally in the footpad and after four months, were sacrificed for the excision of the footpad, liver and spleen. The infection did not exert great influence on the body weight of the mice. The weight of the liver and spleen showed reduction in the undernourished groups when compared to the nourished groups. The macroscopic lesions, viability index and total number of fungi found in the footpads of the infected mice were increased in G3 when compared to G1. Regarding the histopathological analysis of the footpad, a global cellularity increase in the composition of the granuloma was observed in G3 when compared to G1, with large numbers of macrophages and multinucleated giant cells, discrete numbers of lymphocytes were present in G3 and an increase was observed in G1. The results suggest that there is considerable interaction between Jorge Lobo's disease and nutrition.
\end{abstract}

KEYWORDS: Jorge Lobo's disease; Lacazia loboi; Malnutrition; Mice; Histopathology.

\section{INTRODUCTION}

The interaction between nutrition and infection has been considered one of the major problems for the development and survival of humans ${ }^{11,21}$. There are many studies evaluating the effect of malnutrition on mice infected with Toxoplasma gondii, Schistosoma mansoni, Leishmania chagasi, Staphylococcus aureus and Mycobacterium tuberculosis $s^{6,9,10,15,16,24}$, however, there aren't studies relating nutritional aspects to the Jorge Lobo's disease so far.

Jorge Lobo's disease, also known as lobomycosis or lacaziosis, is a chronic, granulomatous, cutaneous-subcutaneous, fungal infection caused by the fungus Lacazia loboi (L. loboi) and is characterized by isolated or multiple coalescing lesions that can occur clinically in a localized or disseminated form ${ }^{13,18,34}$.

In 2007, a study by BRITO et al..$^{3}$ related 318 diagnosed cases of such disease in Brazil, predominantly in the Amazon region, with a total of 490 cases estimated worldwide ${ }^{3}$. In 2010, a study by WOODS et al..$^{34}$ described 249 patients who were attended to the Department of Sanitary Dermatology, Rio Branco, Acre, Brazil, between 1998 and 2008 ${ }^{34}$. The number of patients is relatively small, but the real situation of the disease as a public health problem is not known, because Jorge Lobo's disease is not a disease of compulsory notification.

This mycosis is more common in males due to their occupational activities, and is generally manifested in people aged between twenty and forty-one, coinciding with their work-related activities, when they are naturally exposed to the pathogen ${ }^{27,29}$.

Histopathologically, this mycosis is characterized by an intense and diffuse histiocytic reaction, often with fibrosis, restricted to the dermis, consisting of large numbers of multinucleated giant cells (MGC), both foreign body-type and Langhans-type, and numerous fungi mainly inside these cells. Plasma cells, neutrophils and a small number of lymphocytes are also presented ${ }^{12,17,26}$.

An immunohistochemical study conducted by VILANI-MORENO et al. ${ }^{28}$ showed that inflammatory cell infiltrates presented the following frequency order: macrophages $\mathrm{CD}^{+} 8^{+}>\mathrm{T}$ lymphocytes $\mathrm{CD}^{+}(\mathrm{T}$ lymphocytes $\mathrm{CD}^{+}>$T lymphocytes $\left.\mathrm{CD}^{+}\right)>$Natural Killer cells $\mathrm{CD} 57^{+}$ $>$ Plasma cells $\mathrm{CD} 79^{+}>\mathrm{B}$ lymphocytes $\mathrm{CD} 20^{+}$. According to the authors, the large amount of fungi in the lesions, the disorganized granuloma and the changes in the profile of the Th2 cell cytokine pattern, suggest that

(1) Instituto Lauro de Souza Lima, Biology Technical Team, Bauru, SP, Brasil.

(2) Instituto Lauro de Souza Lima, Microbiology Technical Team, Bauru, SP, Brasil.

(3) Instituto Lauro de Souza Lima, Animal House, Bauru, SP, Brasil.

(4) Instituto Lauro de Souza Lima, Pathology Technical Team, Bauru, SP, Brasil.

(5) Universidade Estadual Paulista (UNESP), Department of Tropical Diseases and Image Diagnosis, Botucatu Medical School, Botucatu, SP, Brasil.

Fátima Regina Vilani-Moreno and Paulo Câmara Marques Pereira are joint senior contributors.

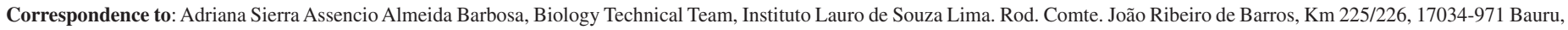
São Paulo, Brasil. Phone: +551431035912 and +5514997255496. E-mail: drisierra@ hotmail.com 


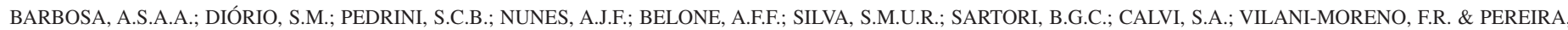
P.C.M. - The relevance of nutritional status and histopathological findings on the infectious process of BALB/c mice inoculated with Lacazia loboi. Rev. Inst. Med. Trop. Sao Paulo, 57(5): 421-6, 2015.

patients showing immunoregulatory disorders with the mycosis might be responsible for the lack of containment of the pathogen.

The fungus $L$. loboi has not been grown in artificial culture media so far; however, MADEIRA et al. ${ }^{14}$ developed an experimental model for the study of Jorge Lobo's disease, by inoculating the fungi obtained from patient's skin lesions, intradermally, into the footpads of BALB/c strain mice. These authors found that eight months post-inoculation, the footpad of the mice showed macroscopic lesions and histological changes, similar to those found in human disease, with a large number of viable fungi.

A more recent study has shown the experimental reproduction of Jorge Lobo's disease in BALB/c mice inoculated with fungi obtained from previously infected mice presenting macroscopic lesions. Hence, $\mathrm{BALB} / \mathrm{c}$ mice is considered an excellent mouse strain for the maintenance of L. loboi in the laboratory ${ }^{2}$.

Considering this, as there had been no other studies on the role of nutritional status in Jorge Lobo's disease, the aim of the present study was to evaluate the effects of the protein-calorie malnutrition (PCM) in $\mathrm{BALB} / \mathrm{c}$ isogenic mice infected with $L$. loboi, by determining the weight of their bodies and organs, the viability index and the total number of fungi in the footpad, and also the histopathological analysis of organs and footpad.

\section{MATERIALS AND METHODS}

Experimental groups: A total of 60 isogenic 12-week-old male BALB/c mice were kept at the Lauro Souza Lima Institute. All animals were housed in plastic cages (five mice per cage) with white wood chips for bedding and access to commercial food Nuvilab CR-1 (Nuvital, Colombo, PR, Brazil), which is specifically made for the feeding of laboratory rodents, drinking water, under controlled lighting (12-h day/12-h night cycle) and temperature $\left(22 \pm 2{ }^{\circ} \mathrm{C}\right)$ conditions. The animals were distributed into four groups: (G1) 15 mice inoculated with the fungus and under dietary restriction, (G2) 15 mice not inoculated with the fungus and under dietary restriction, (G3) 15 mice inoculated with the fungus and on a normal diet and (G4) 15 mice not inoculated with the fungus and on normal diet. The research project was approved by the Ethics Committee on Animal Experiments of the Botucatu School of Medicine, UNESP.

Fungal suspension: L. loboi was obtained from the footpads of BALB/c mice previously inoculated for maintenance of the strain ${ }^{2}$. The animals were sacrificed and the footpads were removed and macerated in $0.9 \%$ sterile saline. The fungal suspension (pool) obtained was evaluated with respect to the number of fungi and its viability was determined by vital staining with fluorescein diacetate-ethidium bromide, as described for L. loboi by VILANI-MORENO \& OPROMOLLA ${ }^{31}$ The strain used in our experiments was molecularly characterized according to VILELA et $a .^{32}$.

Inoculation: Mice were inoculated intradermally in both hind footpads with $0.03 \mathrm{~mL}$ of fungal suspension containing $1.4 \times 10^{6}$ fungi, with inoculum concentration of $4.8 \times 10^{7} / \mathrm{mL}$ and viability index of $38 \%$.

Diet and weight of the animals: Before the start of the study, all animals were weighed; the animals in groups $\mathrm{G} 1$ and $\mathrm{G} 2$ were submitted, for 20 days, to a restricted diet with a daily offer of $80 \%$ of the quantities ingested by groups G3 and G4. The dietary restriction was conducted in order to achieve a weight loss of about $20 \%$. Twenty days after receiving a normal diet or dietary restriction, the animals were infected. After the inoculation, the animals of groups G1 and G2 remained on dietary restriction until the period they had to be sacrificed, at the final moment. All groups of animals were weighed monthly. The food and animals were weighed on a digital scale with $0.25 \mathrm{~g}$ to $5,000 \mathrm{~g}$ precision (model AS5500C Marconi, Piracicaba, SP, Brazil).

Euthanasia of the animals: Four months after the inoculation (period necessary for the appearance of the macroscopic lesions in the footpads, according to BELONE et al. $^{2}$ ), the animals were euthanized using carbon dioxide $\left(\mathrm{CO}_{2}\right)$. The liver and spleen were excised and weighed on a digital scale with $0.01 \mathrm{~g}$ to $210 \mathrm{~g}$ precision (model Metler Toledo AB204, Barueri, SP, Brazil) and the material underwent histopathological evaluation. The footpads were excised to determine the viability index and the total number of fungi, and also to perform the histopathology.

Histological sections of organs and footpads: The footpads and organs were fixed in $10 \%$ buffered formalin for 24 hours, and then prepared to be embedded in paraffin, according to the usual technique. Histological sections of $4 \mu \mathrm{m}$ thick were stained with Hematoxylin-Eosin (HE) and Gomori's methenamine silver (GMS $)^{8}$.

Histopathological evaluation: The slides of the HE-stained organs underwent histopathological evaluation and the GMS-stained slides were examined for the presence of fungi in the organs. The HE-stained footpad slides were used to examine the characteristics of dermal inflammatory infiltrate as well as cell elements: macrophages, lymphocytes, neutrophils, plasma cells and MGC were quantified on a semi-quantitative $0-4+$ scale where: $0=$ absent, $1=$ minimal, $2=$ mild, $3=$ moderate, $4=$ intense $\mathrm{e}^{17,30}$. The GMS-stained slides were examined for the presence of fungi in the footpads, and the findings were semi-quantified on a $0-4+$ scale as described above.

Statistical Analysis: All data were analyzed with the SAS for Windows software, version 9.2. The Tukey test was performed for the analysis of the following variables: body weight, liver, spleen and fungi viability index. Poisson or negative binomial distributions were used for the analysis of the number of fungi, followed by the Likelihood-ratio test. In all cases, the significance level was set at $5 \%$.

\section{RESULTS}

Regarding animal weight, at the first moment, no significant differences were observed among the studied groups. Then, the animals in groups $\mathrm{G} 1$ and $\mathrm{G} 2$ were submitted to dietary restriction, while the animals in groups G3 and G4 received a normal diet. At the time of inoculation, a significant decrease was observed in the weight of the animals in groups G1 and G2 and a significant increase in weight was observed in the animals from groups G3 and G4, when compared to the initial conditions of each group $(p<0.05)$. After the 4-month period, there were no significant differences in the weight of the animals from groups G1 and G2. There was a significant increase, however, in the weight of the animals from groups G3 and G4, when compared to the moment of inoculation of each group $(p<0.05)$ (Table 1$)$. 


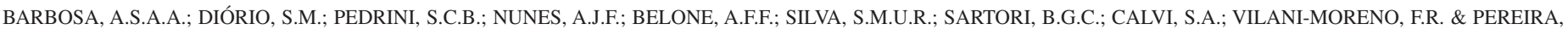

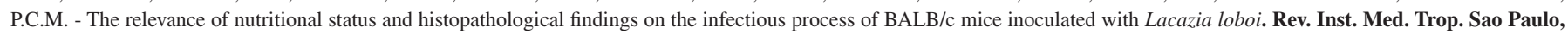
57(5): 421-6, 2015.

Table 1

Body, liver and spleen weights, in grams, of BALB/c mice according to the study groups and the moments of determination

\begin{tabular}{lcccccccccc}
\hline & \multicolumn{4}{c}{ Body Weight } & \multicolumn{4}{c}{ Final } & \multicolumn{3}{c}{ Liver } & \multicolumn{2}{c}{ Spleen } \\
\cline { 2 - 14 } Groups & \multicolumn{2}{c}{ Initial } & \multicolumn{2}{c}{ Inoculation } & \multicolumn{2}{c}{ Weight } \\
\cline { 2 - 13 } & $\bar{x}$ & $s^{2}$ & $\bar{x}$ & $s^{2}$ & $\bar{x}$ & $s^{2}$ & $\bar{x}$ & $s^{2}$ & $\bar{x}$ & $s^{2}$ \\
\hline G1 & 25.75 & $1.33 \mathrm{aA}$ & 21.37 & $1.18 \mathrm{bA}$ & 21.57 & $1.09 \mathrm{bA}$ & 1.08 & $0.18 \mathrm{~A}$ & 0.07 & $0.02 \mathrm{~A}$ \\
G2 & 26.13 & $2.37 \mathrm{aA}$ & 21.28 & $1.89 \mathrm{bA}$ & 21.03 & $2.14 \mathrm{bA}$ & 1.09 & $0.21 \mathrm{~A}$ & 0.05 & $0.01 \mathrm{~A}$ \\
G3 & 26.36 & $1.71 \mathrm{aA}$ & 27.83 & $1.72 \mathrm{bB}$ & 32.47 & $1.91 \mathrm{cB}$ & 1.76 & $0.30 \mathrm{~B}$ & 0.14 & $0.03 \mathrm{~B}$ \\
G4 & 24.38 & $0.97 \mathrm{aA}$ & 27.63 & $1.63 \mathrm{bB}$ & 32.58 & $1.63 \mathrm{cB}$ & 1.60 & $0.15 \mathrm{~B}$ & 0.12 & $0.02 \mathrm{~B}$ \\
\hline
\end{tabular}

Initial: before the animals were subjected to a diet restriction. Inoculation: the animals intradermally inoculated both footpads with $L$. loboi. Final: four months after the inoculation. (G1) mice inoculated with the fungus and under dietary restriction, (G2) mice not inoculated with the fungus and under dietary restriction, (G3) mice inoculated with the fungus and on a normal diet and (G4) mice not inoculated with the fungus and on a normal diet. $\bar{x}$ : means and $s^{2}$ : standard deviations. Means and standard deviations followed by the same lower-case letter (line) showed no significant difference by the Tukey test at a level of 5\%. Means followed by the same capital letter (column) showed no significant difference by the Tukey test at a level of 5\%. Initial body weights: G1=G2=G3=G4. Inoculation body weights: G1, G2 < G3, G4. Final body weights: G1, G2 < G3, G4. Liver weight: G1, G2 < G3, G4. Spleen weight: G1, G2 < G3, G4.

There has been a significant interaction between the effect of the diet and the studied groups, as the weight of the liver and spleen of the malnourished groups G1 and G2 showed significantly lower values when compared to the groups with no dietary restrictions $\mathrm{G} 3$ and $\mathrm{G} 4$ ( $p$ $<0.05$ ) (Table 1).

The histopathological analysis of the liver and spleen showed no differences among the studied groups. In accordance with the weight of the organs, histological sections of the liver revealed atrophic hepatocyte trabeculae in the malnourished groups (G1 and G2), while in both groups inoculated with the fungus L. loboi (G1 and G3), the liver showed vacuolar degeneration and more intense nuclear reactivity when compared to the non-inoculated groups. Histological sections of the spleen revealed only sinusoidal congestion in all groups. The study of fungi, through histopathological analysis, revealed that GMS-stained sections of the liver and spleen, in the inoculated groups (G1 and G3), showed no dissemination of fungi to these organs.

The footpads of the animals of the two groups (G1 and G3) showed macroscopic lesions, which in general were higher in group G3 (inoculated) when compared to group G1 (Fig. 1A and 1B).

The total number of fungi recovered from the footpads of the infected animals (G1 and G3) was $1.95 \times 10^{6} / \mathrm{mL}$ in G1 and $3.22 \times 10^{6} / \mathrm{mL}$ in $\mathrm{G} 3(p<0.05)$. The viability index of $L$. loboi was higher in G3 animals $(41.8 \%)$ when compared to G1 animals $(32.2 \%)(p<0.05)$.

The histopathological study of the footpads of the mice inoculated with L. loboi, G1 and G3, irrespective of the PCM, showed similar morphological patterns. We observed the presence of inflammatory infiltrate predominantly composed by macrophages (4+) and MGC, both foreign body-type and Langhans-type, and numerous fungi mainly inside these cells, many of them with morphological characteristics of viability (Fig. 1C and 1D).

In group G3, lymphocytes were present in discrete numbers $(2+)$ and were dispersed between macrophages or forming small clumps around blood vessels, macrophages and MGC. Neutrophils were present

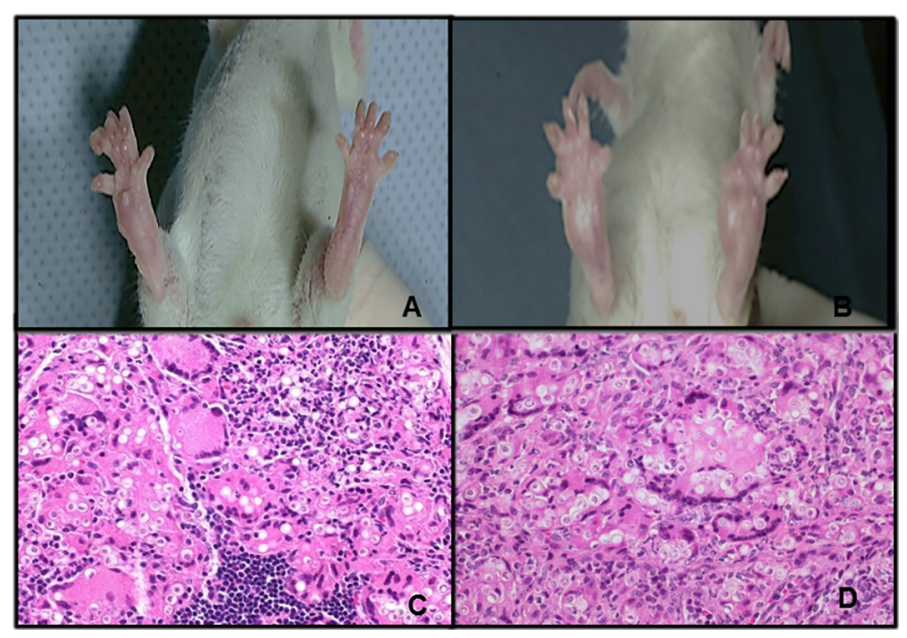

Fig. 1 - Macroscopic aspect of the footpad of mice inoculated with Lacazia loboi, four months after inoculation. A: G1; B: G3. Histological aspect with presence of macrophages, multinucleated giant cells and numerous fungi (HE, 20x). C: G1; D: G3. (G1) mice inoculated with the fungus and under dietary restriction, (G3) mice inoculated with the fungus and on normal diet.

in moderate numbers (3+), also disperse in the infiltrate or aggregated forming microabscesses. Scattered areas with more lymphocytes or neutrophils were observed, although the neutrophils were always present in greater numbers (Fig. 1D and Fig. 2).

In group $\mathrm{G} 1$, the inflammatory infiltrate was less intense in comparison to that of group G3. However, these animals showed an increase in the number of lymphocytes (3+), while their number of neutrophils did not change (3+). Cell distribution was similar in both groups G1 and G3, and rare plasma cells were observed (Fig. 1C and Fig. 2).

\section{DISCUSSION}

Jorge Lobo's disease is a rare mycosis that occurs predominantly in the Brazilian Amazon region. Unknown factors are related to the 


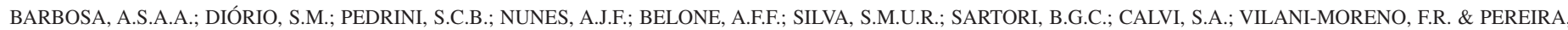
P.C.M. - The relevance of nutritional status and histopathological findings on the infectious process of BALB/c mice inoculated with Lacazia loboi. Rev. Inst. Med. Trop. Sao Paulo, 57(5): 421-6, 2015.

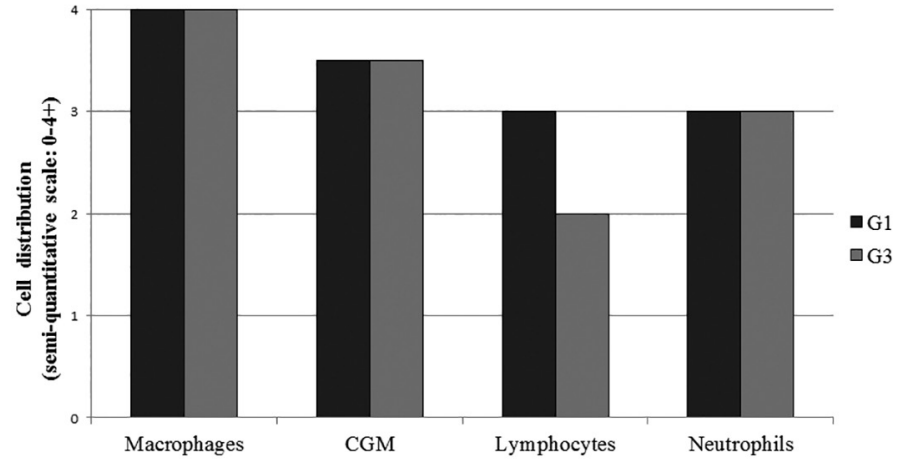

Fig. 2 - Frequency of cells in histological section of the footpad of BALB/c mice according to the study group. G1: mice inoculated with the fungus and under dietary restriction; G3: mice inoculated with the fungus and on normal diet; CGM: multinucleated giant cells.

predisposition or protection from the development of the disease in affected individuals ${ }^{12,28}$. In addition, there are no studies available evaluating the nutritional changes related to this mycosis.

The experimental model of malnutrition used in the present study, in which mice previously underwent PCM and subsequently were inoculated with the pathogen, has been successfully used in several other studies with the following pathogens: Toxoplasma gondii, Staphylococcus aureus and Mycobacterium tuberculosis $5^{6,9,10,24}$.

In experimental studies of PCM, body weight is one of the most widely used indicators for evaluation of the nutritional status ${ }^{33}$. The results revealed that the infection by $L$. loboi did not have great influence in the body weight of the mice that received a normal diet when compared to the control group. Thus, both infected groups (G1and G3) presented similar behavior compared to their respective control groups, accordingly to the results described earlier ${ }^{6,9,10,16,24}$.

According to ABREU et al. ${ }^{1}, \mathrm{PCM}$ is the cause of several clinical manifestations, but the most apparent changes are those that occur in measurements and mass, much of the body as a whole or in specific organs such as the liver and spleen.

The liver and spleen have a significant role in both the nutritional and infectious processes. In PCM, histological changes, as well as the weight of these organs may reflect nutritional changes ${ }^{5,16}$. In the present study, the weight of the liver and spleen of the malnourished group showed a significantly reduction when compared to groups without food restriction, as described earlier in the literature related to other pathologies ${ }^{4,5,25}$.

In this study, the histopathological analysis of the spleen showed only sinusoidal congestion in all groups. The analysis of the liver showed that the inoculated groups (G1 and G3) presented vacuolar degeneration and more intense nuclear reactivity. The most relevant difference found was related to the weight of the organs between the nourished (G3 and G4) and malnourished groups (G1 and G2), characterized by atrophic hepatocyte trabeculae in the malnourished groups. Due to the fact that malnutrition is a chronic condition and the fungi which causes Jorge Lobo's disease does not spread to other organs, histological GMS-stained sections did not reveal the presence of fungi in the liver and spleen.
The study of COUTO et al. ${ }^{5}$, about changes on the liver function in mice with schistosomiasis associated with malnutrition showed that both infection and/or malnutrition interfered in the levels of hepatic biochemical indicators, but the most important changes in liver function occurred during the intense inflammatory process caused by schistosomiasis, leading to increased liver enzymes.

Regarding the histopathological study of the liver, studies performed by OLIVEIRA et al. ${ }^{16}$ and COUTINHO et al. ${ }^{4}$ showed that malnutrition affects several regenerative mechanisms, such as decreased fibroblast proliferation, and synthesis of collagen and albumin. They also showed that the nutritional status of the host plays an important role in changing the connective tissues in murine hepatic schistosomiasis.

Another important aspect to be highlighted is the appearance of macroscopic lesions on the footpad that were smaller in malnourished animals (G1) when compared to the nourished group (G3). A less intense inflammatory reaction was also observed in the nourished group. The viability index and total number of fungi found in the footpads of the inoculated mice showed an increase in the nourished mice when compared to the malnourished mice. As there are no other studies linking malnutrition and Jorge Lobo's disease, the comparisons of our results are restricted to the inoculated mice with no dietary restriction.

Studies by MADEIRA et al. ${ }^{14}$ with BALB/c mice, and VILANIMORENO \& OPROMOLLA ${ }^{31}$ in cutaneous lesions of humans, showed viability indexes similar to those found in our study. Also, a research conducted by BELONE et al. ${ }^{2}$ with mice inoculated with $L$. loboi showed that the number of fungi recovered at four months after inoculation was similar to ours.

Regarding the histopathological analysis of footpads, increased global cellularity in the composition of granuloma in the nourished group was observed in comparison to that of the malnourished group, in addition to the proportional increase of lymphocytes in the malnourished group. Studies with malnourished mice inoculated with Staphylococcus aureus ${ }^{6}$ and Mycobacterium tuberculosis ${ }^{9,10}$ showed a decrease in the number of peripheral blood lymphocytes, suggesting that these cells may be migrating to the site of infection, similar to the results found in our study.

These findings are important and lead to the hypothesis that malnutrition in Jorge Lobo's disease can cause certain resistance to fungal growth, characterized by the lower viability index, total number of fungi and reduced size of footpads found in the malnourished group. This fact is unexpected because malnutrition has been most commonly associated with increased susceptibility to infectious agents ${ }^{11,21}$. However, this finding could be explained by the competition for nutrients between the host and the pathogen, as described in other studies ${ }^{22,23}$.

Similar results were reported by FRANÇA et al. ${ }^{6}$ in an experimental study with BALB/c mice inoculated with Staphylococcus aureus using the same model of malnutrition as ours. This study showed that malnourished mice had a smaller amount of bacteria in the lungs compared to the nourished mice.

The study of OARADA et al. ${ }^{20}$ with BALB/c mice inoculated with Paracoccidioides brasiliensis (P. brasiliensis) using diet of $1.5 \%$ casein showed higher antifungal activity in the liver and spleen when compared 


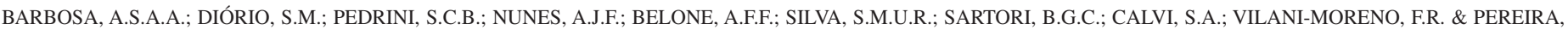

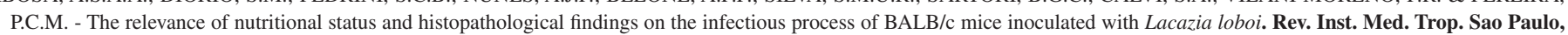
57(5): 421-6, 2015.

with the $20 \%$ casein diet, suggesting that protein restriction led to increased host resistance to $P$. brasiliensis. In another study, OARADA et al. ${ }^{19}$ found a greater number of fungi in the liver and spleen when using a diet of $54 \%$ protein, when compared to a 5 and $20 \%$ casein diet. According to the authors, the results suggest that a higher protein diet reduces host resistance to $P$. brasiliensis. It's an interesting finding since $P$. brasiliensis and $L$. loboi have many similarities. A survey of the phylogenetic analysis of $L$. loboi held by HERR et al. ${ }^{7}$ suggested that L. loboi is a dimorphic fungus, taxonomically related to P. brasiliensis and that they belong to the Onygenales order, Ajellomycetaceae family, which could explain the similarity of results in our study.

When all the results are analyzed in conjunction, one important conclusion is that there is an interaction between Jorge Lobo's disease and nutrition, and as most patients have low socioeconomic conditions and are likely to present nutritional deficiency, new studies are needed to clarify the mechanisms involved in this interaction, especially considering that in humans the disease may develop in localized and disseminated clinical forms.

\section{RESUMO}

\section{A relevância do estado nutricional e alterações histopatológicas no processo infeccioso de camundongos BALB/c inoculados com Lacazia loboi}

O objetivo do estudo foi avaliar os efeitos da desnutrição protéico-calórica em camundongos isogênicos da linhagem BALB/c inoculados com Lacazia loboi, empregando parâmetros nutricionais e histopatológicos. Foram constituídos quatro grupos: G1- inoculados com restrição dietética; G2- não inoculados com restrição dietética; G3- inoculados sem restrição dietética; G4- não inoculados sem restrição dietética. Após instalada a desnutrição, os animais foram inoculados via intradérmica no coxim plantar e após quatro meses foram sacrificados para remoção do coxim plantar, fígado e baço. A infecção não exerceu grande influência no peso corporal dos camundongos. O peso do fígado e baço apresentou redução nos grupos desnutridos em comparação aos grupos nutridos. A lesão macroscópica, a viabilidade e o número total de fungos dos coxins plantares dos camundongos inoculados revelaram aumento no G3 quando comparado com o G1. Em relação à análise histopatológica dos coxins plantares observou-se aumento da celularidade global na composição do granuloma no $\mathrm{G} 3$ em relação ao G1, com grande número de macrófagos e células gigantes multinucleadas, discretos números de linfócitos estavam presentes em G3 e aumentados no G1. Os resultados sugerem que existe grande interação entre nutrição e doença de Jorge Lobo.

\section{CONFLICT OF INTEREST}

The authors declare that there are no conflicts of interest.

\section{REFERENCES}

1. Abreu MAMM, Weckx LLM, Hirata CHW. Histological and ultrastructural aspects of the tongue in undernourished rats. Rev Bras Otorrinolaringol. 2006;72:523-7.

2. Belone AFF, Madeira S, Rosa PS, Opromolla DVA. Experimental reproduction of the Jorge Lobo's disease in BALB/c mice inoculated with Lacazia loboi obtained from a previously infected mouse. Mycopathologia. 2002;155:191-4.
3. Brito AC, Quaresma JAC. Lacaziose (doença de Jorge Lobo): revisão e atualização. An Bras Dermatol. 2007;82:461-74.

4. Coutinho EM, Silva FL, Barros AF, Araújo RE, Oliveira SA, Luna CF, et al. Repeated infections with Schistosoma mansoni and liver fibrosis in undernourished mice. Acta Trop. 2007;101:15-24.

5. Couto JLA, Vieira RCS, Barbosa JM, Machado SS, Ferreira HS. Alterações da função hepática de camundongos desnutridos e infectados pelo Schistosoma mansoni. Rev Soc Bras Med Trop. 2008;41:390-3.

6. França TGD, Ishikawa LLW, Zorzella-Pezavento SFG, Chiuso-Minicucci F, Guerino $\mathrm{CPF}$, Cunha MLRS, et al. Immunization protected well nourished mice but not undernourished ones from lung injury in Methicillin-resistant Staphylococcus aureus (MRSA) infection. BMC Microbiol. 2009;9:240-7.

7. Herr RA, Tarcha EJ, Taborda PR, Taylor JW, Ajello L, Mendoza L. Phylogenetic analysis of Lacazia loboi places this previously uncharacterized pathogen within the dimorphic Onygenales. J Clin Microbiol. 2001;39:309-14.

8. Grocott RG. A stain for fungi in tissue sections and smears using Gomori's methenaminesilver nitrate technic. Am J Clin Pathol. 1995;25:975-9.

9. Ishikawa LLW, Rosa LC, França TGD, Peres RS, Chiuso-Minicucci F, Zorzella-Pezavento SFG, et al. Is the BCG vaccine safe for undernourished individuals? Clin Dev Immunol. 2012;2012:673186.

10. Ishikawa LLW, França TGD, Chiuso-Minicucci F, Zorzella-Pezavento SFG, Marra NM, Pereira PCM, et al. Dietary restriction abrogates antibody production induced by a DNA vaccine encoding the mycobacterial $65 \mathrm{kDa}$ heat shock protein. Genet Vaccines Ther. 2009;7:11

11. Kau AL, Ahern PP, Griffin NW, Goodman AL, Gordon JI. Human nutrition, the gut microbiome, and immune system: envisioning the future. Nature. 2011;474(7351):32736 .

12. Lacaz CS, Porto E, Martins JEC, Heins-Vaccari EM, Melo NT. Tratado de micologia médica Lacaz. 9 $^{\text {th }}$ ed. São Paulo: Sarvier; 2002.

13. Lacaz CS, Baruzzi RG, Rosa MCB. Doença de Jorge Lobo. São Paulo: Ed. USP-IPSIS; 1986.

14. Madeira S, Opromolla DVA, Belone AFF. Inoculation of BALB/C mice with Lacazia loboi. Rev Inst Med Trop Sao Paulo. 2000;42:239-43.

15. Malafaia G, Serafim TD, Silva ME, Pedrosa ML, Rezende AS. Protein-energy malnutrition decreases immune response to vaccine in BALB/c mice. Parasite Immunol. 2009;31:41-9.

16. Oliveira SA, Silva LM, Barbosa Junior AA, Ribeiro-Dos-Santos R, Coutinho EM Andrade ZA, et al. Decreased humoral and pathologic responses in undernourished mice infected with Schistosoma mansoni. Parasitol Res. 2004;93:30-5.

17. Opromolla DVA, Belone AFF, Taborda PRO, Taborda VBA. Correlação clínico patológica em 40 casos novos de blastomicose. An Bras Dermatol. 2000;75:425-34.

18. Opromolla DVA, Taborda PR, Taborda VBA, Viana S, Furtado JF. Lobomicose: relato de 40 casos novos. An Bras Dermatol. 1999;74:135-41.

19. Oarada M, Igarashi M, Tsuzuki T, Kamei K, Hirasaka K, Nikawa T, et al. Effects of a high-protein diet on host resistance to Paracoccidioides brasiliensis in mice. Biosci Biotechnol Biochem. 2010;74:620-6.

20. Oarada M, Kamei K, Gonoi T, Tsuzuki T, Toyotome T, Hirasaka K, et al. Beneficial effects of a low-protein diet on host resistance to Paracoccidioides brasiliensis in mice. Nutrition. 2009;25:954-63. 


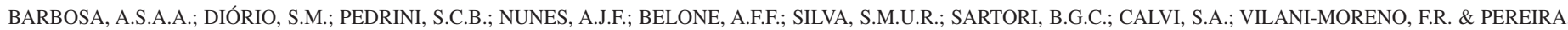
P.C.M. - The relevance of nutritional status and histopathological findings on the infectious process of BALB/c mice inoculated with Lacazia loboi. Rev. Inst. Med. Trop. Sao Paulo, 57(5): 421-6, 2015

21. Pereira PCM. Interação entre infecção, nutrição e imunidade na medicina tropical. In: Cimerman S, Cimerman B, editores. Medicina tropical. São Paulo: Atheneu; 2003. p. $655-60$.

22. Prentice AM, McDermid J. The host-pathogen battle for micro-nutrients. Annu Rev Nutr. 2008. doi: 10.1146/annurev.nutr.28.061807.1555.27

23. Potrykus J, Ballou ER, Childers DS, Brown AJP. Conflicting interests in the pathogen-host tug of war: fungal micronutrient scavenging versus mammalian nutritional immunity. PLOS Pathog. 2014;10:e1003910.

24. Ribeiro DA, Pereira PCM, Machado JM, Silva SB, Pessoa AWP, Salvador DMF. Does toxoplasmosis cause DNA damage? An evaluation in isogenic mice under normal diet or dietary restriction. Mutat Res. 2004;559:169-76.

25. Serafim TD, Malafaia G, Silva ME, Pedrosa ML, Rezende SA. Immune response to Leishmania (Leishmania) chagasi infection is reduced in malnourished BALB/c mice. Mem Inst Oswaldo Cruz. 2010;105:811-7.

26. Talhari C, Oliveira CB, Santos MNS, Ferreira LC, Talhari S. Disseminated lobomycosis. Int J Dermatol. 2008;47:582-3.

27. Vilani-Moreno FR, Mozer E, Sene AMG, Perasçoli MO, Pereira TC, Miras MG, et al. In vitro and in situ activation of the complement system by the fungus Lacazia loboi. Rev Inst Med Trop Sao Paulo. 2007;49:97-101.

28. Vilani-Moreno FR, Belone AFF, Soares CT, Opromolla DVA. Immunohistochemical characterization of the cellular infiltrate in Jorge Lobo's disease. Rev Iberoam Micol. $2005 ; 22: 44-9$.
29. Vilani-Moreno FR, Silva LM, Opromolla DV. Evaluation of the phagocytic activity of peripheral blood monocytes of patients with Jorge Lobo's disease. Rev Soc Bras Med Trop. 2004;37:165-8.

30. Vilani-Moreno FR, Fecchio D, Mattos MCI, Moscardi-Bacchi M, Defaveri J, Franco M. Study of pulmonary experimental paracoccidioidomycosis by analysis of bronchoalveolar lavage cells: resistant vc. susceptible mice. Mycopathologia. 1998;141:79-91.

31. Vilani-Moreno FR, Opromolla DVA. Determinação da viabilidade do Paracoccidioide loboi em biópsias de pacientes portadores de doença de Jorge Lobo. An Bras Dermatol. 1997;72:433-7.

32. Vilela R, Mendoza L, Rosa PS, Belone AFF, Madeira S, Opromolla DVA, et al. Molecular model for studying the uncultivated fungal pathogen Lacazia loboi. J Clin Microbiol. 2005;43:3657-61.

33. Waitzberg DL, Lotierzo PHP, Silva AJD, Schronts E, Cerra F. Imunonutrição. In: Waitzberg DL, editor. Nutrição oral, enteral e parenteral na prática clínica. $3^{\text {rd }}$. ed. São Paulo: Atheneu; 2000. p. 1-38

34. Woods WJ, Belone AFF, Carneiro LB, Rosa PS. Ten years experience with Jorge Lobo's disease in the state of Acre, Amazon region, Brazil. Rev Inst Med Trop Sao Paulo. 2010;52:273-8.

Received: 16 September 2014

Accepted: 2 February 2015 